\title{
PERANCANGAN SISTEM INFORMASI BALAI KESEHATAN TNI AL PANGKALAN JATI MENGGUNAKAN METODE WATERFALL
}

\author{
1) Duwi Cahya Putri Buani, ${ }^{2)}$ Indah Suryani \\ Teknik Informatika, STMIK Nusa Mandiri Jakarta \\ 1)dputribuani8@gmail.com, ${ }^{2)}$ ihy.indah@gmail.com
}

\begin{abstract}
Balai Kesehatan TNI Angkatan Laut Pangkalan Jati requires a system that can solve the problems that occur there, these problems can be solved by the implementation of computerized system that the author design, waterfall method proved to be used to design the system very well, the fifth stage method waterfall ie Requirement Analysis, System Design, Implementation, Integration \& Testing and Operation \& Maintenance can well translate the system needs on Balai Kesehatan TNI Angkatan Laut Pangkalan Jati.
\end{abstract}

\section{Keywords: Balai Kesehatan, System Design, Waterfall}

Abstrak - Balai Kesehatan TNI Angkatan Laut Pangkalan Jati membutuhkan sekali sistem yang dapat menyelesaikan permaslahan-permasalahan yang terjadi disana, permasalahan-permasalahan tersebut dapat diselesaikan dengan adanya penerapan sistem terkomputerisasi yang penulis rancang, metode waterfall terbukti dapat digunakan untuk merancang sistem dengan sangat baik, kelima tahap metode waterfall yaitu Requirement Analisis, System Design, Implementation, Integration \& Testing dan Operation \& Maintenance dapat dengan baik menterjemahkan kebutuhan-kebutuhan sistem pada Bali Kesehatan TNI Angkatan Laut pangkalan Jati.

\section{Kata Kunci: Balai Kesehatan, Sistem Design, Waterfall}

\section{A. PENDAHULUAN}

Pelayanan kesehatan adalah salah satu fasilitas yang di berikan oleh pemerintah terhadap warga negaranya seperti yang diatur dalam Undang-Undang Dasar 1945 pasal 28 $H$ dan Undang-Undang Nomor 23/1992 tentang Kesehatan, pemerintah menetapkan bahwa setiap orang berhak mendapatkan pelayanan kesehatan. salah satu fasilitas kesehatan yang ada adalah balai kesehatan yang di biayai oleh pemerintah untuk melayani kesehatan warga negaranya.

Balai Kesehatan TNI Angkatan Laut Pangkalan Jati adalah balai kesehatan bagi keluarga TNI Angkatan Laut, Anggota TNI Angkatan Laut dan Pasien Umum. Pelayanan yang diberikan meliputi Pendaftaran Pasien Baru, Pendaftaran Pasien Lama, Pencatatan Rekam Medis, dan pembayaran obat.

Dalam lingkup pelayanan yang begitu luas tentunya banyak sekali permasalahan kompleks yang terjadi dalam proses pelayanan di Balai Kesehatan. Banyak yang turut menentukan kecepatan arus informasi yang dibutuhkan oleh pengguna dan lingkungan Balai Kesehatan. Pengelolaan data merupakan salah satu komponen yang penting dalam mewujudkan suatu sistem. Pengelolaan data secara manual, mempunyai banyak kelemahan, selain membutuhkan waktu yang lama, juga kurang dapat diterima, karena kemungkinan kesalahan sangat
besar(Handoyo,dkk :2008). Pengelolaan data pasien di rumah sakit merupakan salah satu komponen yang penting dalam mewujudkan pelayanan rumah sakit berkualitas. Pengelolaan data yang lambat dan kurang akurat akan sangat mempengaruhi pelayanan rumah sakit terhadap pasien (Topan,dkk, 2015). Oleh karena itu Balai Kesehatan TNI Angkatan Laut Pangkalan jati membutuhkan sistem informasi yang tepat sehingga akan mengurangi kendala-kendala administrasi yang sering terjadi, dan permasalahanpermasalahan yang terjadi pada Balai Kesehatan TNI Angkatan Laut Pangkalan Jati penulis kelompokan menjadi:

1. Lamanya pelayanan terhadap pasien dikarenakan bagian administrasi harus mendata pasien terlebih dahulu sebelum berobat. Hal ini dikarenakan bagian administrasi harus mencari data rekamedik yang tertumpuk di dalam arsip.

2. Adanya kesulitan dalam mengontrol perlengkapan dan peralatan di dalam balai kesehatan contohnya adalah obat yang masuk dan keluar tidak terkontrol sehingga data fisik barang atau obat dengan data laporan tidak sesuai.

3. Data rekamedik pasien hanya di simpan dalam bentuk arsip sehingga jika data tersebut hilang maka pasien akan membuat data rekamedik baru, sedangkan untuk melihat riwayat kesehatan seorang 
pasien harus melihat data rekamedik sebelumnya.

4. Keterlambatan dalam membuat laporan terutama laporan data pasien, laporan data obat, laporan data rekamedik, laporan data penyakit dan laporan data pendapatan balai kesehatan TNI Angkatan Laut.

\section{B. TINJAUAN PUSTAKA}

\section{Sistem Informasi}

Menurut Mustakini (2005) Sistem informasi adalah suatu sistem di dalam suatu organisasi yang mempertemukan kebutuhan pengolahan transaksi harian, mendukung operasi, dan kegiatan strategi dari suatu organisasi dan menyediakan kepada pihak luar tertentu dengan laporan-laporan yang diperlukan.

\section{Program}

Program adalah rangkaian instruksiinstruksi dalam bahasa komputer yang tersusun secara logis dan sistematis. (Sugiyono, 2005). Selain itu proses pemrograman komputer bukan hanya sekedar menulis suatu urutan instruksi yang harus dikerjakan oleh komputer akan tetapi bertujuan untuk memcahkan suatu masalah serta membuat mudah pekerjaan pengguna komputer (user), didalam membuat sebuah program komputer, tentu tidak terlepas dari sifat individu pemrograman (Programmer).

\section{Microsoft Visual Basic $\mathbf{6 . 0}$}

Dalam penelitian ini program yang akan dibuat menggunakan aplikasi Microsoft Visual basic 6.0 dan Cristal Report 8.0. Visual basic adalah bahasa pemprograman yang berbasis windows yang merupakan object oriented programming (OOP), yaitu pemprograman yang berorientasi objek. Menurut (Subari dan Yuswanto, 2008:1). Program Visual Basic adalah sebuah bahasa pemrograman berbasis visual. Visual Basic 6.0 selain disebut sebagai bahasa pemrograman (language program), juga sering disebut sebagai sarana (tool) untuk menghasilkan program-program aplikasi berbasis windows.

\section{UML (Unified Modeling Language)}

Menurut Widodo dalam Chonoles (2011:06), "UML singkatan dari Uniferd Modeling Language yang berarti bahasa pemodelan standar memiliki sintaks dan sematik". UML mempunyai sejumlah elemen grafis yang bisa dikombinasikan menjadi diagram. Diagram menggambarkan atau mendokumentsikan beberapa aspek dari sebuah system. Berikut adalah klasifikasi diagram yang ada pada UML:

a) Use Case Diagram

Use case adalah eskripsi fungsi dari sebuah system dari perspektif pengguna (Munawar, 2005:63). Use case bekerja dengan cara mendeskripsikan tipikal interaksi antara user (pengguna) sebuah system dengan sebuah sistemnya sendiri melalui sebuah cerita bagaimana sebuah system dipakai. Urutan langkahlangkah yang menerangkan anatara pengguna dan system disebut scenario. Setiap scenario mendeskripsikan urutan kejadian, setiap urutan diinisialiasasikan oleh orang, system yang lain, perangkat keras atau urutan waktu. Dengan demikian secara singkat bisa dikatakan use case adalah serangkaian scenario yang digabungkan bersama-sama oleh tujuan umum pengguna.

b) Class Diagram

Class diagram UML digambarkan dengan kotak, class adalah spesifikasi yang jika diinstansiasi akan menghasilakn sebuah objek dan merupakn inti dari pengembangan dan desain berorientasi objek. Class menggambarkan keadaan (atribut/propeti) suatu system, sekaligus menawarkan layanan untuk memanipulasi keadaan tersebut (metode/fungsi).

c) Statechart Diagram

Statechart diagram atau yang biasa juga disebut state diagram digunakan untuk mendokumentasikan beragaam kondisi/keadaan yang bisa terjadi terhadap sebuah class dan kegiatan apa saja yang dapat merubah kondisi/keadaan tersebut. Pada umunya statechart diagram menggambarkan class tertentu (satu class dapat memliki lebih dari satu statechart diagram).

d) Activity Diagram

"Activity diagram adalah teknik untuk mendiskripsikan logika procedural, proses bisnis dan aliran kerja dalam bnyak kasus. Activity diagram seperti sebuah flow chart. Activity diagram ini sangat berguna untuk menunjukan operasi sebuah objek dan proses bisnis. Kelelebihan activity diagram dibandingkan flow chart adalah kemampuannnya dalam menampilkan aktifitas paralel. Activity diagram bisa digunakn untuk menunjukan siapa mengerjakan apa dengan teknik partision (Munawar, 2005b:118)."

e) Sequence Diagram

Sequence diagram digunakan untuk menggambarkan perilaku pada sebuah scenario (Munawar, 2005:87). Diagram ini menunjukan sebuah contoh objek dan message atau pesan yang 
diletakkan diantara objek-objek ini didalam use case diagram.

f) Collaboration Diagram

Collaboration Diagram adalah perluasan dari obyek diagram (Objek diagram yang menunjukan obyek-obyek dan hubungnnya satu sama lainnya). Collaboration diagram menunjukan message-message obyek yang dikirimkan satu sama lain (Munawar, 2005:101). Bila sequence diagram diorganisir menurut waktu maka collaboration diagram diurut menurut ruang atau scape.

g) Component Diagram

Component sofware adalah bagian fisik dari sebuah system, karena menetap di komputer buka dibenak para analis. Komponen bisa berupa table, file, file exe dan lain-lain. Sebuah komponen bisa mengakses service yang ada pada komponen yang lain. Komponen ini menyediakan service tersebut disebut export interface sedangkan yang mengaksesnya disebut import interface. Component Diagram menggambarkan struktur dan hubungan antar komponen piranti lunak termasuk ketergatungan (dependency) (Munawar, 2005:119).

h) Deployment Diagram

Deployment diagram menunjukan tata letak sebuah system secara fisik, menampakkan bagian-bagian software yang berjalan pada bagian hardware (Munawar, 2005:125).

i) Package Diagram

Package adalah pengelompokan konstruksi yang memungkinkan untuk mengambil konstruksi tersebut di UML dan mengelompokan elemen-elemen tersbut secara bersama-sama menjadi level yang lebih tinggi (Munawar, 2005:129).

\section{ERD (Entity Relationship Diagram)}

Entity Relationship Diagram merupakan suatu model untuk menjelasakn hubungan antar data dalam basis data brdasarakan suatu persepsi bahwa real word terdiri dari object-object dasar mempunyai hubungan atau relasi antar object-object tersebut, relasi antar object dilukiskan dengan menggunakan simbol-simbol grafis tertentu (Marlinda, 2004:17).

\section{METODE PENELITIAN}

Untuk menyelesaikan permasalahanpermasalahan yang telah disebutkan sebelumnya maka penulis membuat Sistem
Informasi yang nantinya akan dapat memecahkan permasalahan tersebut. Untuk membuat sistem tersebut penulis menggunakan metode Waterfall untuk menganalisa kebutuhan sistem.

Metode air terjun atau yang sering disebut metode waterfall sering dinamakan siklus hidup klasik (classic life cycle), dimana hal ini menggambarkan pendekatan yang sistematis dan juga berurutan pada pengembangan perangkat lunak, dimulai dengan spesifikasi kebutuhan pengguna lalu berlanjut melalui tahapan-tahapan perencanaan (planning), permodelan (modeling), konstruksi (construction), serta penyerahan sistem ke para pelanggan/pengguna (deployment), yang diakhiri dengan dukungan pada perangkat lunak lengkap yang dihasilkan (Pressman, 2012). Tahapan metode waterfall dapat dilihat pada gambar di bawah ini.

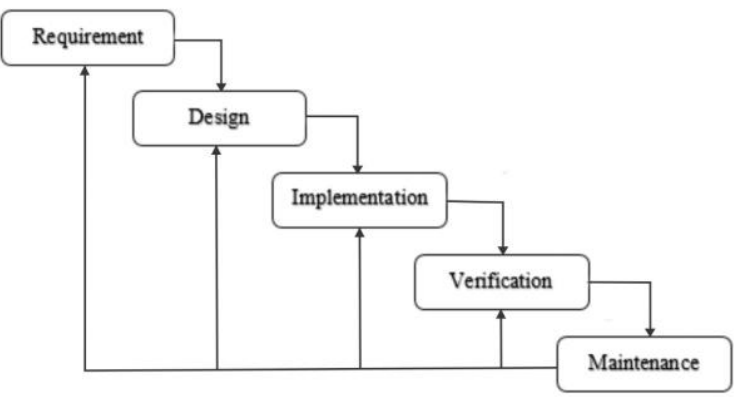

Sumber: Pressman(2012)

Gambar 1. Tahapan Metode Waterfall

\section{Tahapan Metode Waterfall}

Dalam pengembangannya metode waterfall memiliki beberapa tahapan yang berurut yaitu: requirement (analisis kebutuhan), design system (desain sistem), Coding (pengkodean) \& Testing (pengujian), Penerapan Program, pemeliharaan. Tahapan tahapan dari metode waterfall adalah sebagai berikut :

a) Requirement Analisis

Tahap ini pengembang sistem diperlukan komunikasi yang bertujuan untuk memahami perangkat lunak yang diharapkan oleh pengguna dan batasan perangkat lunak tersebut. Informasi ini biasanya dapat diperoleh melalui wawancara, diskusi atau survei langsung. Informasi dianalisis untuk mendapatkan data yang dibutuhkan oleh pengguna.

b) System Design

Spesifikasi kebutuhan dari tahap sebelumnya akan dipelajari dalam fase ini dan desain sistem disiapkan. Desain Sistem membantu dalam menentukan perangkat keras(hardware) dan sistem 
persyaratan dan juga membantu dalam mendefinisikan arsitektur sistem secara keseluruhan.

c) Implementation

Pada tahap ini, sistem pertama kali dikembangkan di program kecil yang disebut unit, yang terintegrasi dalam tahap selanjutnya. Setiap unit dikembangkan dan diuji untuk fungsionalitas yang disebut sebagai unit testing.

d) Integration \& Testing

Seluruh unit yang dikembangkan dalam tahap implementasi diintegrasikan ke dalam sistem setelah pengujian yang dilakukan masing-masing unit. Setelah integrasi seluruh sistem diuji untuk mengecek setiap kegagalan maupun kesalahan.

e) Operation \& Maintenance

Tahap akhir dalam model waterfall. Perangkat lunak yang sudah jadi, dijalankan serta dilakukan pemeliharaan. Pemeliharaan termasuk dalam memperbaiki kesalahan yang tidak ditemukan pada langkah sebelumnya. Perbaikan implementasi unit sistem dan peningkatan jasa sistem sebagai kebutuhan baru.

\section{Kelebihan Metode Waterfall}

Kelebihan menggunakan metode air terjun (waterfall) adalah metode ini memungkinkan untuk departementalisasi dan kontrol. proses pengembangan model fase one by one, sehingga meminimalis kesalahan yang mungkin akan terjadi. Pengembangan bergerak dari konsep, yaitu melalui desain, implementasi, pengujian, instalasi, penyelesaian masalah, dan berakhir di operasi dan pemeliharaan.

\section{Kelemahan atau Kekurangan Metode Waterfall \\ Kekurangan} metode waterfall adalah metode ini tidak memungkinkan untuk banyak revisi jika terjadi kesalahan dalam prosesnya. Karena setelah aplikasi ini dalam tahap pengujian, sulit untuk kembali lagi dan mengubah sesuatu yang tidak terdokumentasi dengan baik dalam tahap konsep sebelumnya.

\section{HASIL DAN PEMBAHASAN}

Metode yang digunakan dalam menyelesaikan permasalahan yang ada di dalam bali kesehatan TNI Angkatan Laut Pangkalan Jati adalah metode Waterfall. Berikut tahapan-tahapan yang dilakukan oleh penulis untuk merancang sistem informasi pada balai kesehatan TNI Angkatan Laut pangkalan Jati.

\section{Requirement Analisis}

Sebelum melakukan rancangan sistem, perlu adanya analisis terhadap prosedur yang sedang berjalan yang betujuan untuk mengevaluasi permasalahan serta hambatanhambatan yang terjadi dan menganalisa apa yang dibutuhkan sehingga diperlukan perbaikannya. Prosedur sistem yang berjalan pada Balai Kesehatan TNI Angkatal Laut Pangkalan Jati yang berhubungan dengan pelayanan kesehatan adalah sebagai berikut :

a) Prosedur Pendaftaran Pasien Baru Calon Pasien Mengisi Formulir Pendaftaran dan mengambil nomor antrian untuk pemeriksaan, yang selanjutnya formulir tersebut di serahkan kepada bagian administrasi pendaftaran, kemudian bagian administrasi pendaftaran mengecek poli mana yang dituju oleh calon pasien. Jika calon pasien berobat ke Poli Umum maka bagian administrasi akan mencatat data calon pasien kedalam buku pasien poli umum, mencatat data calon pasien kedalam buku kunjungan poli umum, kemudian bagian administrasi membuatkan kartu Rekam Medis berwarna biru dan membuatkan kartu pasien berwarna biru, tapi jika pasien berobat atau berkunjung ke poli gigi maka bagian administrasi akan mencatat data calon pasien kedalam buku daftar pasien poli gigi, mencatat data calon pasien kedalam buku kunjungan pasien, membuatkan kartu Rekam Medis berwarna kuning dan membuatkan kartu pasien berwarna kuning. Kemudian bagian administrasi akan mengkonfirmasi biaya pendaftaran. Setelah pasien melakukan pembayaran maka pasien akan mendapatkan kartu sesuai dengan poli yang dituju.

b) Prosedur Pendaftaran Pasien Lama Pasien menyerahkan kartu pasien kepada bagian administrasi, kemudian bagian administrasi mengecek kartu pasien, setelah di cek maka bagian administrasi mencari kartu Rekam Medis sesuai dengan poli yang dituju oleh pasin, jika kartu Rekam Medis di temukan maka bagian administrasi akan mencatat data Rekam Medis kedalam kartu Rekam Medis pasien dan mencatat data kedalam daftar buku 
kunjungan pasien sesuai dengan poli yang dituju. Selanjutnya bagian administrasi mengkonfirmasi pasien untuk mengantri. Setelah pasien menerima konfirmasi maka pasien akan mengantri.

c) Prosedur Pencatatan Data Rekam Medis.

Bagian administrasi pendaftaran menyerahkan Kartu Rekam Medis kepada bagian administrasi poli, kemudian bagian administrasi poli memanggil pasien untuk diperiksa oleh dokter sesuai dengan nomor antrian dan bagian administrasi poli menyerahkan Kartu Rekam Medis kepada dokter. Dokter memeriksa pasien sesuai dengan keluhan yang dirasakan oleh pasien, setelah dokter melakukan pemeriksaan, dokter mencata hasil kedalam Kartu Rekam Medis dan membuatkan resep untuk pasien.

d) Prosedure Pembayaran Obat Dan Tindakan

Pasien menyerahkan nota resep kepada bagian administrasi apotik, kemudian bagian administrasi apotik mengecek data obat, jika stok obat atau obat yang tercatat di dalam nota resep tersedia makan bagian administrasi apotik akan mengkonfirmasi ketersediaan obata dan harga obat kepada pasien, setelah menerima konfirmasi harga obat, pasien akan membayar resep sesuai dengan harga yang telah di konfirmasi bagian administrasi apotik. Bagian administrasi apotik menerima pembayaran dan bagian administrasi apotik menyerahkan kwitansi asli, obat kepada pasien dan menyimpan kwitansi copy.

e) Prosedur Pembuatan Laporan Data Kunjungan Pasien

Bagian Administrasi Pendaftaran mengambil buku daftar kunjungan pasien, kemudian bagian administrasi pendaftaran pasen membuatkan laporan data kunjungan pasien, yang kemudian diserahkan kepada kepala administrasi. Setelah kepala administrasi mengecek atau menyetujui laporan data kunjungan pasien maka kepala administrasi akan menyerahkan laporan tersebut kepada kepala balai kesehata. f) Prosedure Pembuatan Laporan Data Rekam Medis Pasien.

Bagian Administrasi Apotik akan mengambil kwitansi Copy, kemudian dari kwitansi tersebut akan dibuat laporan data penjualan obat dan laporan data stok obat. Selanjutnya laporan tersebut di serahkan kepada kepala administrasi untuk di periksa, setelah laporan di setujui maka kepala administrasi akan menyerahkan laporan tersebut kepada kepala balai kesehatan.

g) Prosedur Pembuatan Laporan Data Obat

Bagian Administrasi Apotik akan mengambil kwitansi Copy, kemudian dari kwitansi tersebut akan dibuat laporan data penjualan obat dan laporan data stok obat. Selanjutnya laporan tersebut di serahkan kepada kepala administrasi untuk di periksa, setelah laporan di setujui maka kepala administrasi akan menyerahkan laporan tersebut kepada kepala balai kesehatan.

Penulis melakukan analisa dari prosedurprosedur di atas dan dari analisa tersebut akan dibuatkan prosedur baru untuk mengatasi kekurangan-kekurangan sistem sebelumnya dan dari prosedur baru tersebut akan dirancang Sistem Informasi yang lebih user friendly. Berikut adalah prosedur yang dapat penulis usulkan:

1) Prosedur Pendaftaran Pasien

Pasien datang kebagian administrasi pendaftaran pasien, jika pasien baru maka pasien akan mengisi formulir pendaftaran, setelah formulir pendaftaran di isi maka pasien menyerahkan formulir pendaftaran tersebut kebagian administrasi untuk di catat ke dalam form kunjungan pasien dan form pasien baru. Jika pasien lama maka pasien akan memberikan kartu pasien sesuai dengan poli yang dituju, untuk kemudian bagian administrasi mencatat ke dalam buku kunjungan pasien, jika pasien tidak membawa kartu pasien maka bagian administrasi akan mencari data pasien di dalam form kunjungan berdasarkan nama pasien. Setelah data-data pasien sudah di input kedalam buku Kunjungan pasien. Bagian administrasi pendaftaran memberikan no antrian dan mengkonfirmasi jumlah pembayaran 
administrasi, dan member tahu pasien untuk mengantri sesuai dengan poli.

2) Prosedur Pencatatan Data Rekamedis Dokter akan melihat data pasien yang mengantri di dalam form daftar kunjungan, untuk kemudian dokter yang di bantu oleh bagian administrasi poli akan memanggil pasien satu persatu, setelah pasien di panggil maka pasien akan Di periksa oleh dokter, kemudian dokter menginput data rekam medis kedalam form rekam medis, mencatat resep kedalam form resep dan mencatat tindakan yang dilakuka oleh dokter ke dalam form tindakan, kemudian pasien akan mendapatkan nota resep dan nota tindakan yang kemudian akan di bayar ke bagian apotik.

\section{3) Prosedur Pembayaran Resep}

Pasien yang telah di periksa oleh dokter akan menebus dan membayar resep dan tindakan ke bagian apotik, pasien memberikan nota resep dan nota tindakan kemudian bagian administrasi akan melihta no rekam medis yang tercatat di dalam nota resep dan nota tindakan untuk di cek kedalam form daftar rekam medis, jika nomor rekam medis ada maka bagian apotik akan mencari obat yang tercatat di dalam nota resep jika obat tersedia maka bagian apotik akan menginput obat tersebut kedalam form pembayaran resep jika tidak tersedia makan bagian apotik akan menginfirmasi kepada pasien bahwa obat tersebut tidak tersedia. Kemudian bagian apotik akan menginput tindakan yang dilakukan oleh dokter kemudian bagian administrasi menghitung total pembayaran yang harus di lakukan oleh pasien untuk selanjutnya mengkonfirmasi total pembayaran kepada pasien.

4) Prosedur Pembuatan Laporan Master Admin Cukup mengakses form laporan master, kemudian admin memilih laporan mana yang akan di cetak sesuai dengan yang di inginkan oleh kepala balai kesehatan TNI Angkatan Laut dan kemudian Laporan Tersebut diserahkan kepada Kepala Balai Kesehatan TNI Angkatan Laut.

5) Prosedur Pembuatan Laporan Transaksi
Admin Mengakses form laporan transkasi kemudian admin akan memilih laporan transkasi mana yang dbutuhkan oleh kepala Balai Kesehatan TNI Angkatan Laut.

\section{System Design}

Setelah penulis melakukan analisa kebutuhan sistem pada Balai Kesehatan TNI Angkatan Laut tahapan berikutnya yang akan dilakukan adalah disain sistem, penulis menggunakan UML dalam melakukan disain sistem dan menggunakan ERD untuk mendisain database.

a) UML (Unified Modeling Language)

$$
\text { 1) Use Case Diagram }
$$

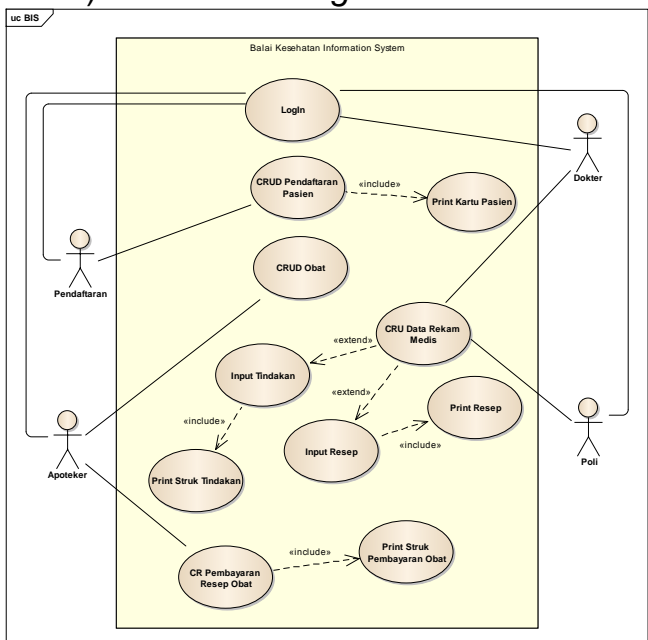

Sumber: Hasil Penelitian

Gambar 2. Use Case Diagram

\section{2) Activity Diagram}

Berikut adalah aktiviti diagram yang terbentuk dari Use Case Diagram yang telah dibuat terlihat pada gambar 2.

(a) Activity Diagram Login

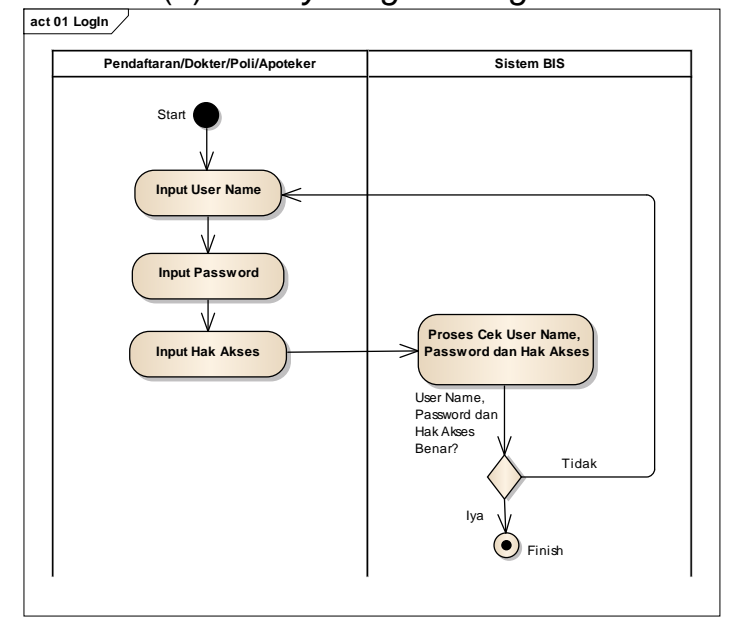

Sumber: Hasil Penelitian

Gambar 3. Activity Diagram Login 
(b) Activity Diagram CRUD Pasien

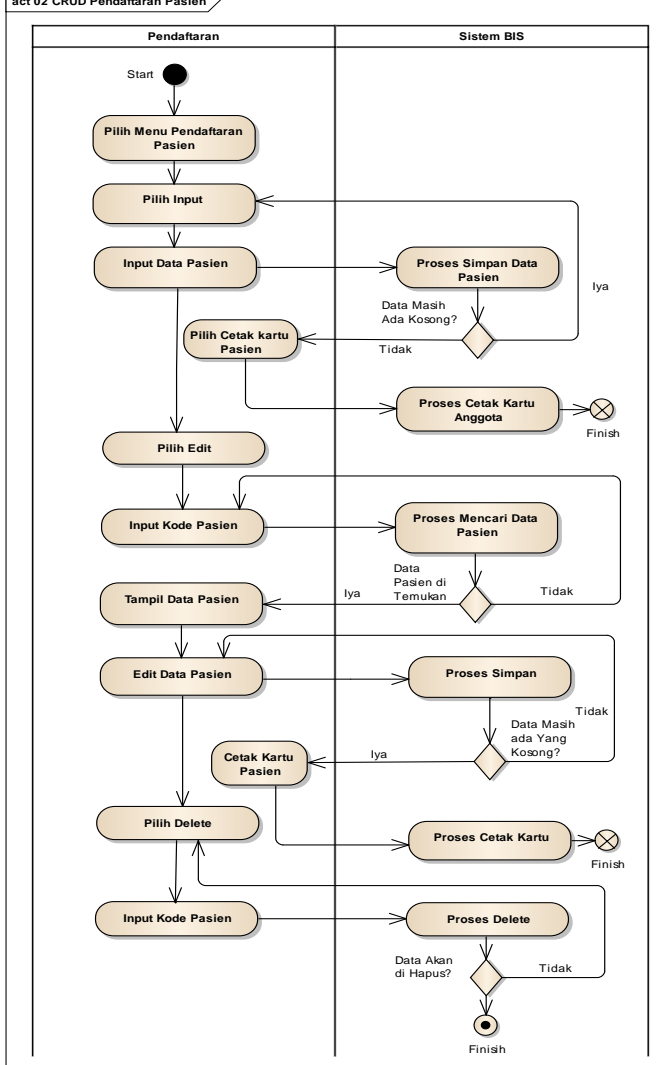

Sumber: Hasil Penelitian

Gambar 3. Activity Diagram Pendaftaran

(c) Activity Diagram CRUD Obat

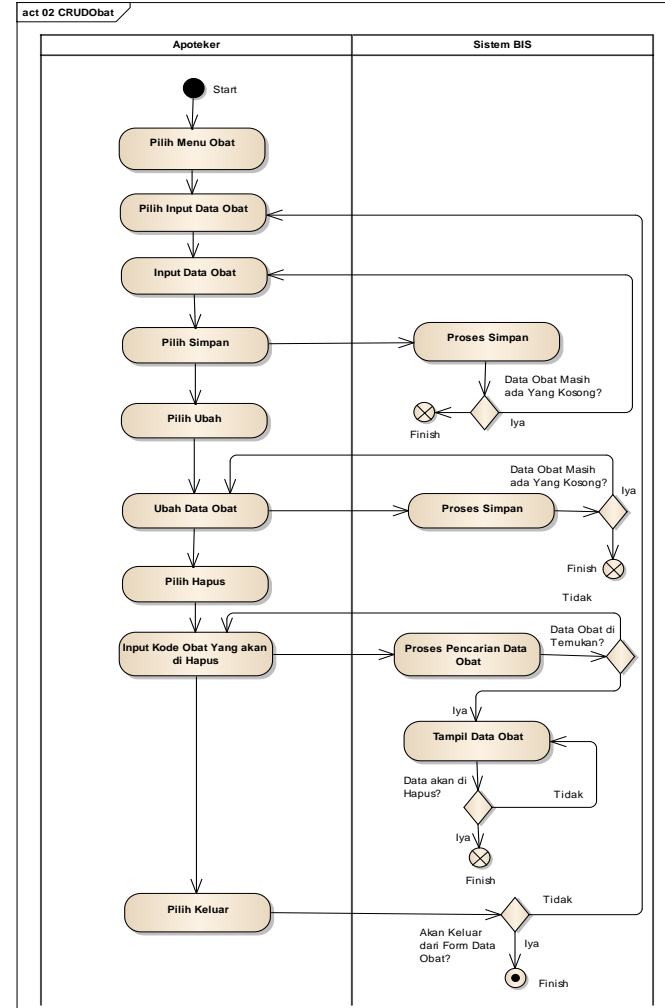

Sumber: Hasil Penelitian

Gambar 4. Activity Diagram CRUD Obat

(d) Activity Diagram CRU Data Rekam Medik

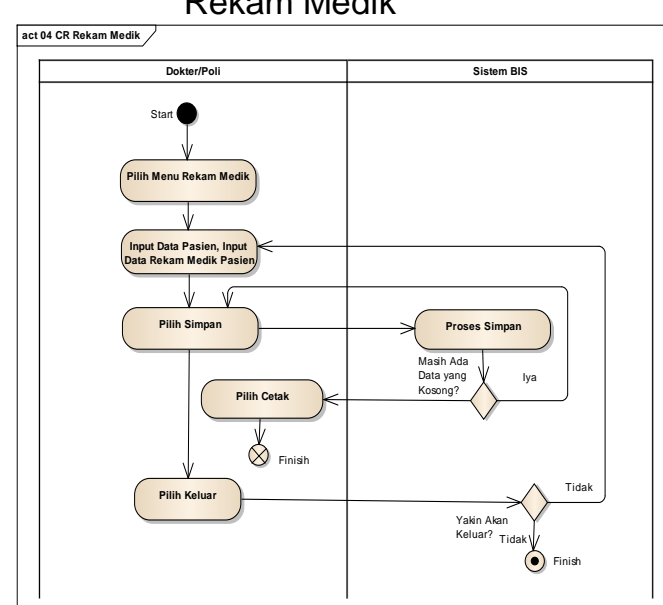

Sumber: Hasil Penelitian

Gambar 5. Activity Diagram CRU Data Rekam Medik

(e) Activity Diagram CRU Data Pembayaran Resep 


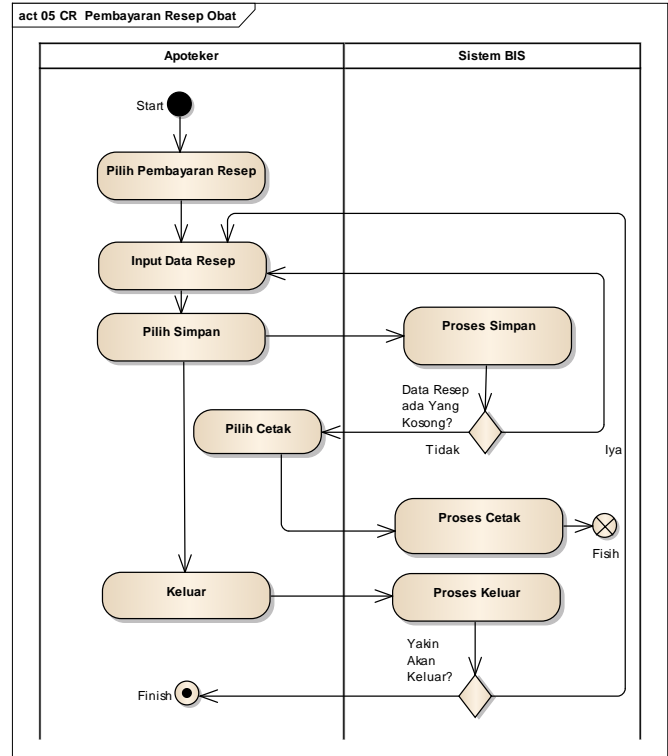

Sumber: Hasil Penelitian

Gambar 6. Activity Diagram CRU

Data Pembayaran Resep

(f) Sequence Diagram

Diagram ini menunjukan sebuah contoh objek dan message atau pesan yang diletakkan diantara objek-objek ini didalam use case diagram.

(1) Sequence Diagram LogIn

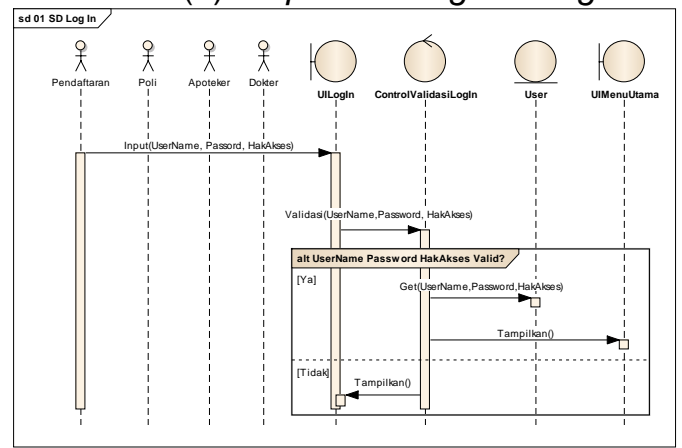

Sumber: Hasil Penelitian

Gambar 7. Sequence Diagram Logln

(2) Sequence

Diagram

Pendaftaran Pasien

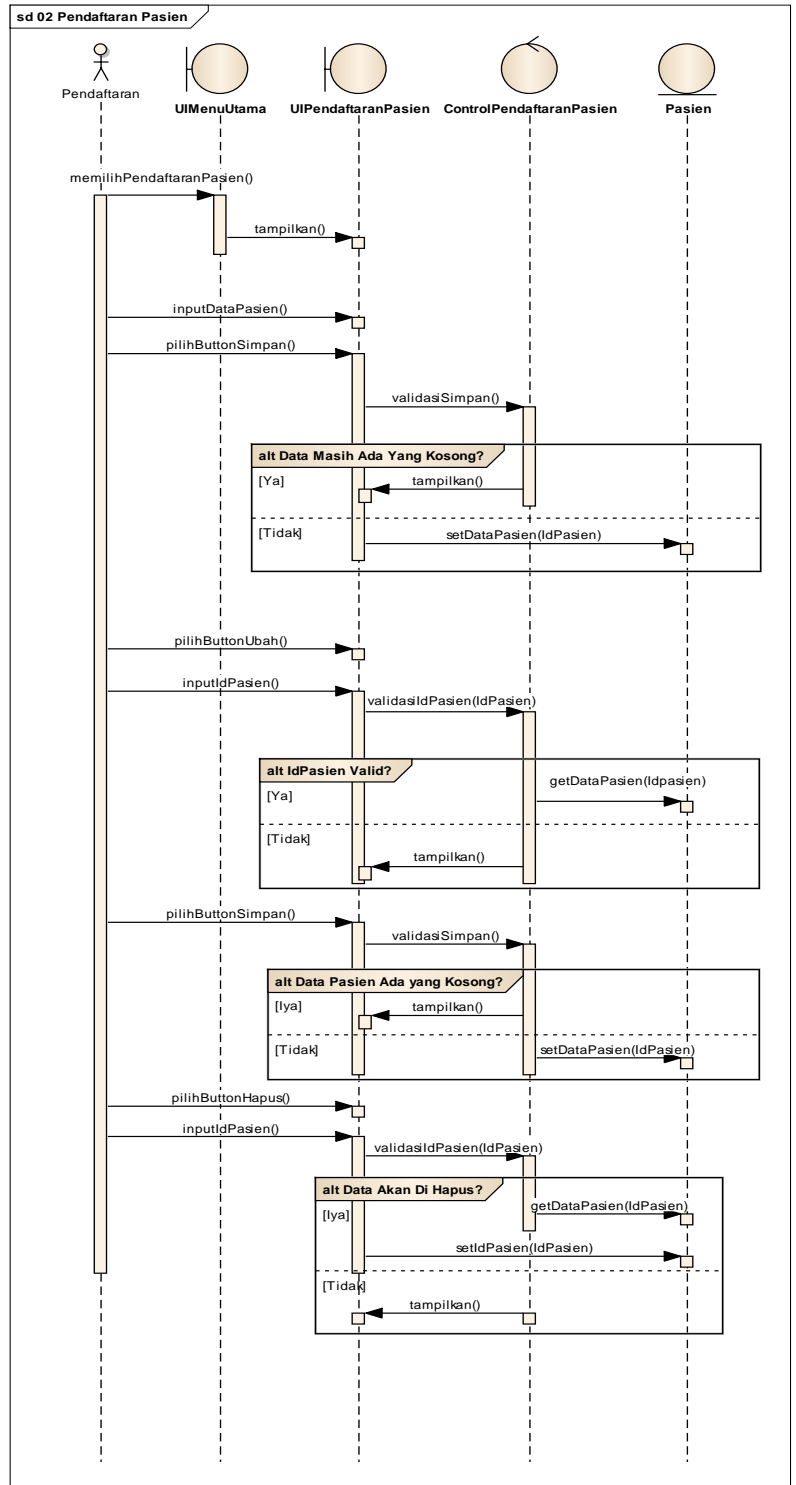

Sumber: Hasil Penelitian

Gambar 8. Sequence Diagram Pendaftaran Pasien
(3) Sequence Diagram CRUD Obat 


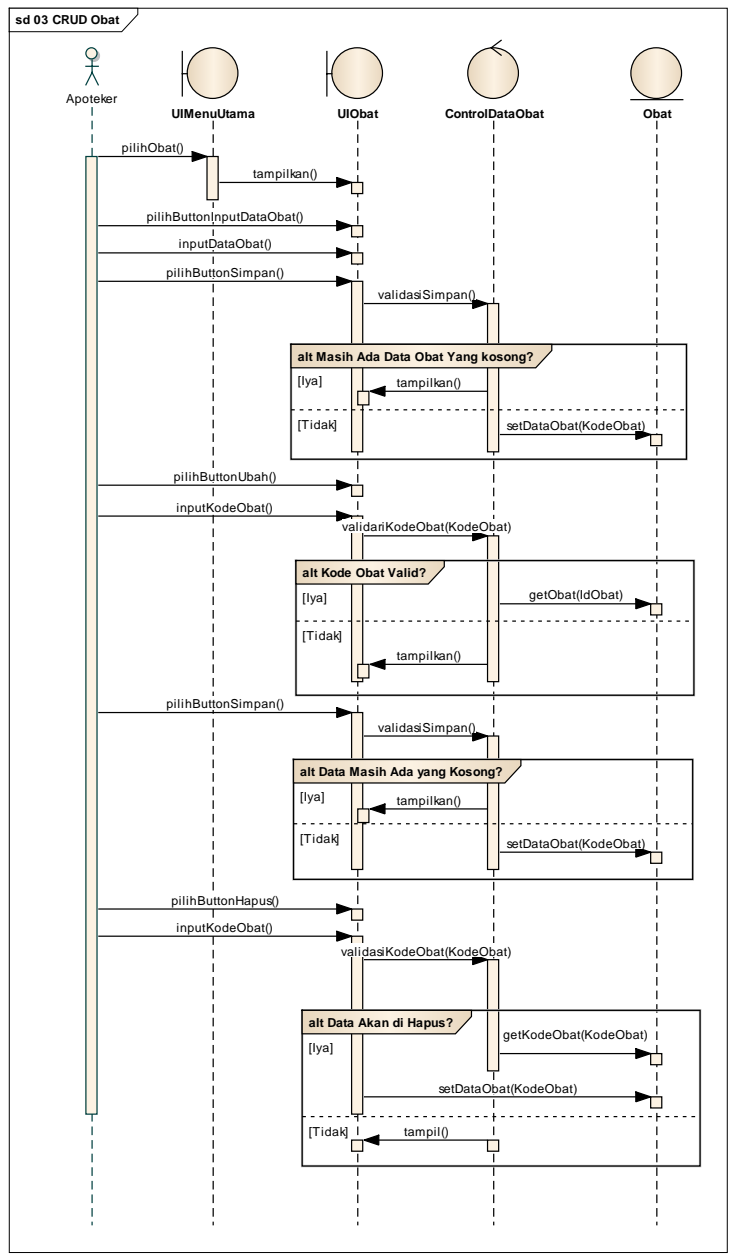

Sumber: Hasil Penelitian

Gambar 9. Sequence Diagram CRUD Obat

(4) Sequence Diagram CR Rekam Medik

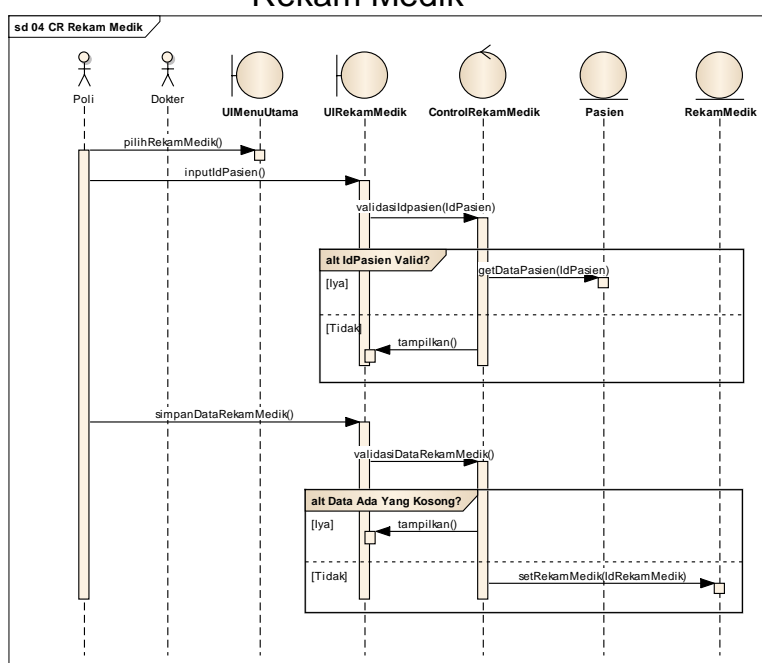

Sumber: Hasil Penelitian

Gambar 10. Sequence Diagram CR Rekam Medik
(5) Sequence Diagram
CR Pembayaran Resep

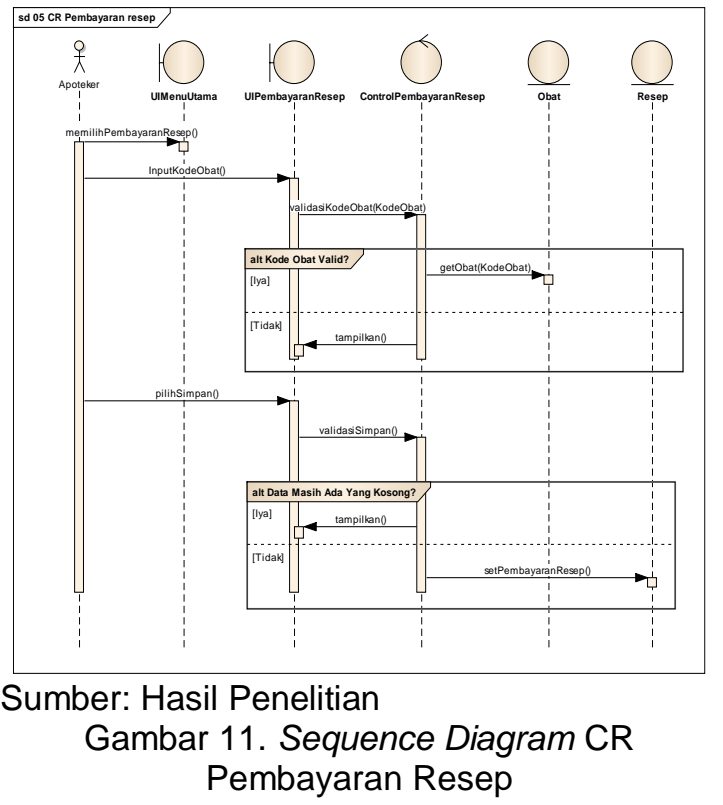

3. ERD(Entity Relationship Diagram)

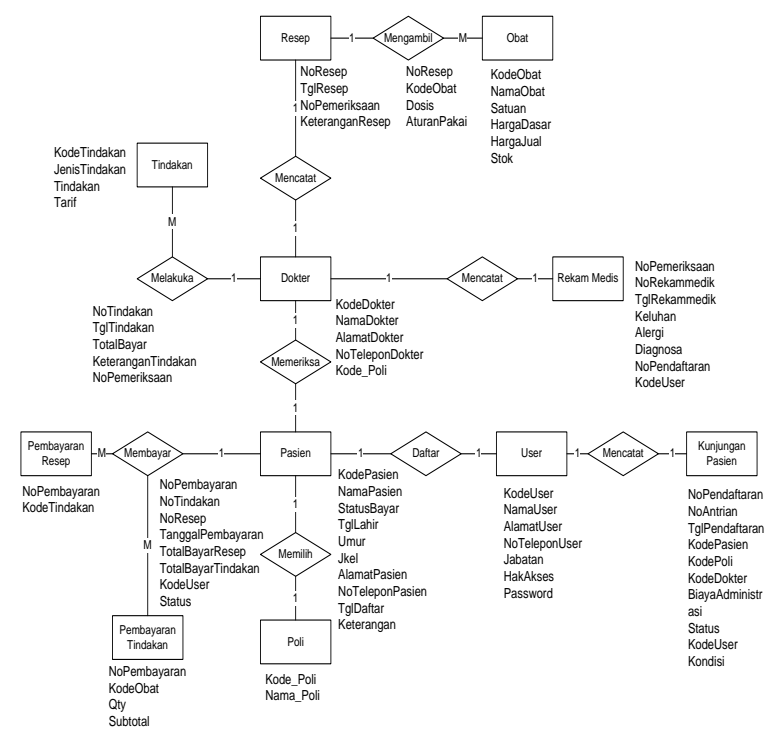

Sumber: Hasil Penelitian

Gambar 12. ERD(Entity Relationship

$$
\text { Diagram) }
$$

\section{Implementation}

Penulis melakukan implementasi dengan menggunakan Visual Basic 6.0, Menurut (Subari dan Yuswanto, 2008). Program Visual Basic adalah sebuah bahasa pemrograman berbasis visual. Visual Basic 6.0 selain disebut sebagai bahasa pemrograman (language program), juga sering disebut sebagai sarana (tool) untuk menghasilkan program-program aplikasi berbasis windows.Dalam pemrograman visual basic 6.0 banyak istilah dan konsep untuk menyebut sesuatu yang membentuk sebuah aplikasi. Istilah-istilah tersebut memiliki arti yang sama dalam lingkungan pemrograman visual 
lainnya, seperti misalnya object, property dan Event.

Selain menggunakan visual basic 6.0 untuk menunjang pembuatan laporan menggunakan Cristal Reports. Menurut Mustakini $(2005,211)$ Cristal Reports merupakan program khusus untuk membuat laporan yang terpisah dari program Microsoft Visul Basic tetapi keduanya dapat dihubungkan (linkage). Hasil cetak dengan menggunakan Cristal Report baik dan lebih mudah, karena pada Cristal Report banyak tersedia objek maupun komponen yang mudah digunakan.

Berikut adalah tampilan User Interface dari aplikasi yang telah dibuat.

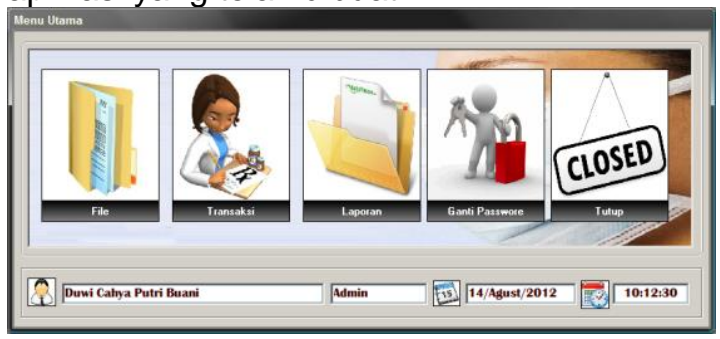

Sumber: Hasil Penelitian

Gambar 13. Tampilan Menu Utama

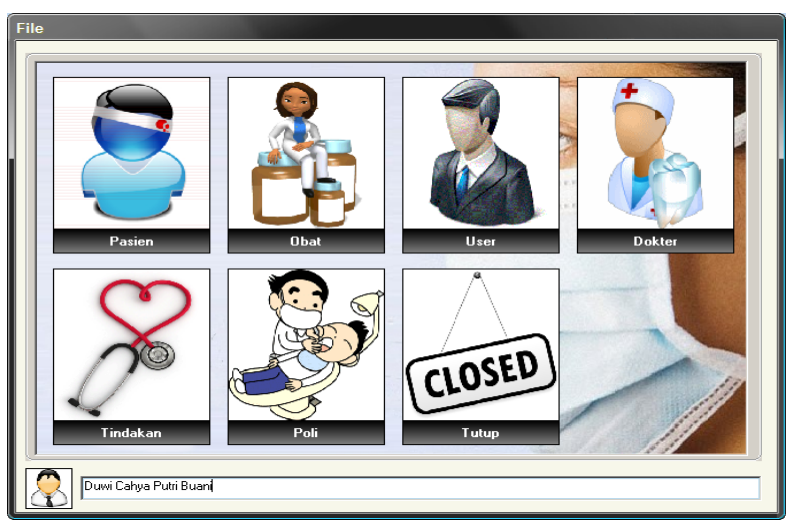

Sumber: Hasil Penelitian

Gambar 14. Tampilan Menu File

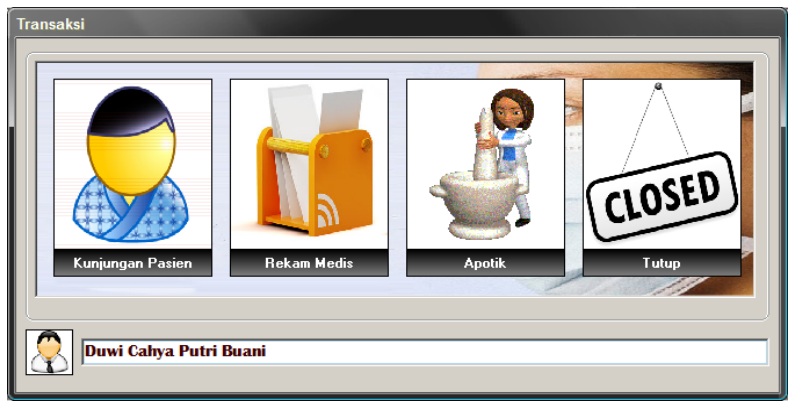

Sumber: Hasil Penelitian

Gambar 15. Tampilan Menu Transaksi

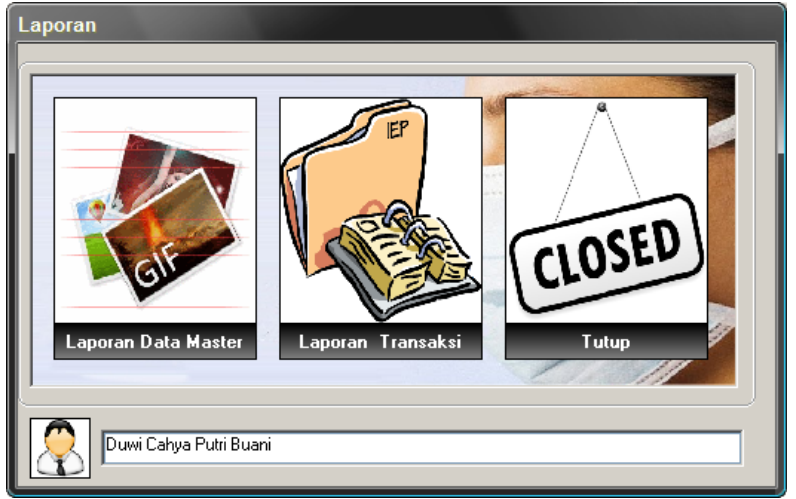

Sumber: Hasil Penelitian

Gambar 16. Tampilan Menu Laporan

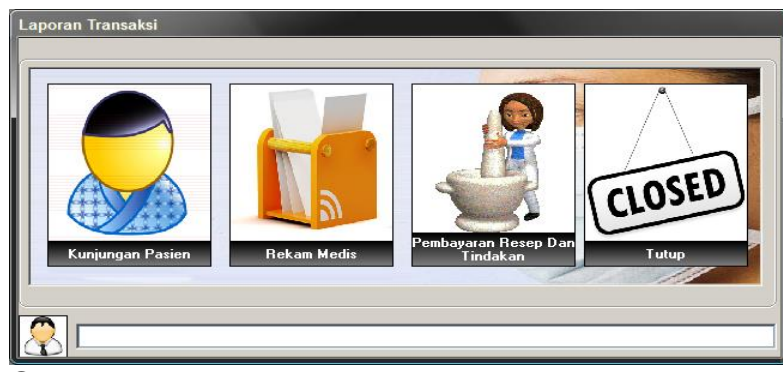

Sumber: Hasil Penelitian

Gambar 17. Tampilan Menu Laporan Transaksi

\section{Integration \& Testing}

Tahapan metode waterfall berikutnya adalah Integration dan Testing, penulis menggunakan Black-Box Testing dalam pengujian aplikasi Balai Kesehatan TNI Angkatan Laut.

Black-Box Testing Menurut Sukamto (2014:275), “yaitu menguji perangkat lunak dari segi spesifikasi fungsional tanpa menguji desain dan kode program". Pengujian dimaksudkan untuk mengetahui apakah fungsi-fungsi, masukan dan keluaran dari perangkat lunak sesuai dengan spesifikasi yang dibutuhkan.

\section{Operation \& Maintenance}

Tahapan terakhir dalam meode Waterfall adalah Operation and Maintenance. Aplikasi diterapkan dan dilakukan Maintenance agar aplikasi dapat berjalan dengan baik dan sesuai dengan fungsinya.

\section{E. KESIMPULAN}

Peranan komputer sangat penting dalam pengolahan data mulai dari penginputan data, penyimpanan data, perubahan data, penghapusan data sampai dengan pencarian data. Dengan adanya komputer semua kegiatan di atas dapat dilakukan dengan cepat, tepat dan akurat.

Balai Kesehatan TNI Angkatan Laut Pangkalan Jati masih menggunakan sistem 
yang manual dalam penginputan data dan pengolahan data. Dengan sistem yang manual ini pengolahan dan penginputan data kurang cepat, tepat, efektif dan efesien. Melihat bahwa kelemahan menggunakan sistem yang manual sangat banyak maka penulis merubah sistem manual yang ada di Balai Kesehatan TNI Angkatan Laut Pangkalan Jati menjadi sistem yang terkomputerisasi dan bahasa pemrograman yang penulis gunakan adalah Microsoft Visual Basic 6.0, yang penulis anggap lebih cepat tepat dan akurat dalam proses pegolahan data.

\section{DAFTAR PUSTAKA}

[1] Handoyo,dkk. (2008). Aplikasi Sistem Informasi Rumah Sakit Berbasis Web Pada Sub- Sistem Farmasi Menggunakan Framework Prado.

[2] Topan, Muhamad. (2015). Perancangan Sistem Informasi Manajemen Rumah Sakit Berbasis Web Studi Kasus : Rumah Sakit TNI AU Lanud Sam Ratulangi

[3] Mustakini, Jogianto Hartono.(2005). Analisa Dan Desain. Yogyakarta: Andi

[4] Sugiyono.(2005). Pemrograman Terstruktur. Jakarta: Panji Gumilang Press

[5] Widodo, Prabowo Pudjo. (2011). Menggunakan UML. Bandung : Informatika Bandung.

[6] Munawar.(2005).Pemodelan Visual dengan UML. Graha IImu : Yogyakarta

[7] Marlinda, Linda. (2004). Sistem Basis Data. Jakarta : Andi

[8] Pressman, Roger S.(2012). Rekayasa Perangkat Lunak- Buku Satu, Pendekatan Praktisi (Edisi 7). Yogyakarta: Andi.

[9] Subari, dan Yuswanto.(2008). Panduan Lengkap Pemrograman Visual Basic 6.0.

[10] Sukamto, Rosa Ariani dan M. Shalahuddin.(2014). Rekayasa Perangkat Lunak Terstruktur dan Berorientasi Objek. Bandung: Informatika. 